\title{
İslâm Mimarî Geleneğinde Mukarnas Unsurunun Ortaya Çıkışı
}

\author{
Dr. Makram HADDAD \\ Marmara Üniversitesi (Mezun) \\ İslâm Tarihi ve Sanatları Ana Bilim Dalı \\ 7addadmakram@gmail.com \\ ORCID: 0000-0002-3443-462X
}

\begin{abstract}
Öz
İslâm mimarisinde görülen geometrik bir bezeme çeşidi olan mukarnas, İslâm mimarisinin en önemli mimari öğelerinden biri olarak da kabul edilir. Buna rağmen ister İslâm medeniyet dairesi içinde yer alan dillerde (özellikle Türkçe ve Arapça literatürlerde) isterse de Batılı dillerde hak ettiği gibi çalışmamış bir konu olduğunu söylemek mümkündür. Bu nedenle mevcut noksanı telafi etmek ve mukarnas konusu üzerinde bazı anlaşılmayan yönleri açıklığa kavuşturabilmek için böyle bir araştırmanın yapılmasına intiyaç duyulmuştur. Bu çalışma sırasında mukarnasa dair terimsel ve tarihî bir tanıtım yapmak adına bu öğenin ilk zuhuru, İslâm dünyasının geniş coğrafyasına yayılması ve bu konulara dair çeşitli görüşler gözden geçirilmiş. Mukarnasın Tanımı, Mukarnasın Menşei, Mukarnasın Maşrıktan diğer İslâm coğrafyasına yayılması ile Mağribî Mukarnasın zuhuru olarak adlandırdığımız dört başlık altında konu genel çizgisiyle sunulmuştur.
\end{abstract}

Anahtar Kelimeler: Mukarnas, Mukarnas Tarihi, i̇slâm Mimarisi

Haddad, M. (2020). İslâm Mimarî Geleneğinde Mukarnas Unsurunun Ortaya Çıkışı. ARTS: Artuklu Sanat ve Beşeri Bilimler Dergisi, 4, ss. 120-139. 


\title{
The Emergence of Muqarnas in the Islamic Architectural Tradition
}

\begin{abstract}
Muqarnas is considered one of the most important architectural elements of Islamic architecture. Despite this, it is possible to say that it is a subject that has not worked as it deserved, whether in Islamic languages (especially Turkish and Arabic literature) or western languages. For this reason, such research was needed to compensate for the existing ambiguous and to clarify some incomprehensible aspects on this subject. During this study, the first occurrence of this element, its spread to the wide geography of the Islamic world and its various views on these issues will be reviewed in order to make a lexical and historical presentation about muqarnas. The definition of Muqarnas, the Origin of Muqarnas, the publishing of Muqarnas from Mashrik to other Islamic geographies will try to present the occurrence of Maghrebian Muqarnas under the general outline of this issue.
\end{abstract}

Keywords: Muqarnas, History of Muqarnas, Islamic Architecture 


\section{arts $s$}

\section{Gíriş1}

İslâm medeniyeti, insanlığa verdiği fikrî ve bilimsel hizmetlerin yanı sıra isılâm'ın sanat anlayışının bir yansıması olan eşsiz abidevî eserler de vermiştir. Bu eserler arasında hat sanatı ve geometrik bezemeler gibi bazı sanatların İslâm medeniyetinin alâmetifârikaları olduğunu söylememiz mümkündür. Bu hususî sanatların arasında mukarnas da önemli bir yer tutar. Mukarnas, ìsâm mimarisinde görülen geometrik bir bezeme çeşididir. Menşei kesin olarak bilinmeyen bu unsur XI. yüzyldan itibaren İslâm coğrafyasının neredeyse tüm bölgelerinde görülmektedir. Mukarnasın tasarımı ve özellikleri dönemden döneme, coğrafyadan coğrafyaya değişiklik gösterir. Ayrıca kullanılan malzeme ve teknik de mukarnasın bölgesel aidiyetini gösterebilir.

Her ne kadar bazı araştırmacılar tarafından mukarnasın aidiyeti konusunda kesin bir bilgi verilebileceği ileri sürülmüş olsa da yine de bu konuda açık bir kanaate sahip olmak kolay değildir. Zira kesin bilimsel dayanakların mevcudiyeti tartışmalıdır. Günümüze ulaşan mukarnas örnekleri zaman açısından yakın olmakla beraber coğrafya bakımından birbirine çok uzak bölgelerde bulunmaktadır. Bazılarına göre İslâm sanat tarihinde rastlanan ilk mukarnas örneği Irak bölgesindedir. Buna mukabil Celal Esat Arseven gibi bazı araştırmacılara göre mukarnasın asıl menşei Orta Asya'dir. Bu nedenle ciddi bir dayanak bulmadan bu konuda kesin bir görüşe sahip olmak, bir kanaate varmak iddiadan öteye geçmeyecektir. Biz de bu araştırma esnasında mümkün mertebe farklı görüşleri dikkate alıp günümüze kadar varabilen en eski mukarnas eserlerini karşılaştırarak inceledikten sonra tatmin edici bir görüşü kurmaya çalışmak cihetine gideceğiz.

\section{YÖNTEM}

Bu araştırma betimsel modele dayalı nitel bir araştırmadır. lilk başła literatür taraması yapılmıs ve konuya dair gerekli veriler toplanmıştı. Veriler; hem ayakta kalan mimari eserlerin maddî vasıfları, hem Türkçe, Arapça, Fransızca, Ingilizce ve Ispanyolca literatürden elde edilen konuyla ilgili sanat tarihi muhtelif eserlerden sağlanmışıı. Araştırmanın ana konusuna dair sanat tarihçilerin farklı görüşleri sunulduktan sonra, geniş literatür taramasından elde edilen delillere dayanarak Mukarnasın menşeine dair yeni bir kanaata varımıştır.

1 Bu makale Prof. Dr. Aziz Doğanay'ın danışmanlığında hazırlanan ve 18.12.2019 tarihinde oy birliği ile kabul edilen "Mağrib bölgesi İslâm Mimârisinde Mukarnas (XVI. Asra kadar) " adlı doktora tezinin ilgili bölümlerinden üretilmiştir. 


\section{MUKARNASIN TANIMI}

İslâm sanat ve mimarisine has bir unsur olan mukarnas, basamaklı çatma taban şeklindeki bir mimari unsurdur. Batıı araşłırmacılar tarafından çoğu zaman istalaktit tabiriyle adlandırılan mukarnas; Arapça, Farsça ve Osmanlı Türkçesi sözlüklerinde "kademeli çıkıntılar olan basamaklı çatma tavan; kubbe; bir başlık türü; rengârenk alacalı işleme" (Mülâyim, 2006, s. 126) gibi tariflerle tanımlanmaktadır. Mukarnasın İslâm mimarisinin simgesel bir unsuru olduğunu söylemek mümkündür. Mukarnas, Arapçadaki karnas² (سنرق) kökünden türetilmiştir (el-Feyrûzabâdî, c. 2, s. 731). Ulaşabildiğimiz kaynaklara göre mukarnas tabirinin kullanıldığı en eski kaynak coğrafyacı ve tarihçi el-Uzrî el-Endelüsî'nin (1003-1085) Tarsi $\square$ Ü'l Ehbâr adlı eseridir (El- $\square$ Uzrî, s. 85). el-Kaş̂' nin (ö. 832/1429) Miftahü'ı Hisâb adlı eserinde de bu sanatsal unsura rastlanmaktadır. Bu eserde, bu çalısmada temas edileceği üzere, mukarnasın farkı çeşitleri, özellikleri ve hücrelerinin yapımı ele alınmıştır. Ayrıca Sâgânî Radıyyüddin'in (ö.650/1252) el- $\square$ Ubâbü'z-zâhir adlı sözlüğünde "karnas" kelimesini

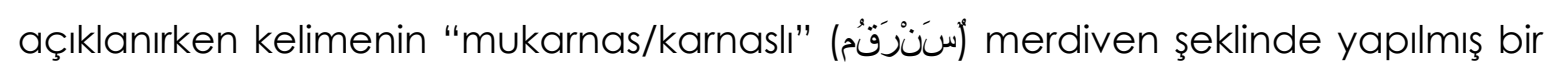
çatı anlamına geldiği ifade edilmiştir (es-Sâganî:, c. 3, s. 408). ${ }^{3}$ el-Fîrûzâbâdî'nin elKamûsü'l-Muhît'i ve ez-Zebîdî'nin Tâcu'l-'Arûs' v gibi muhtelif Arapça lugatlarda da "mukarnas" (سَنْرَقُقُمَ) kelimesinin benzer anlamlarla karşllandığı görülmektedir (elFeyrûzabâdî, c. 1, s. 565; ez-Zebîdî, c. 16, s. 369). Bu lugatlarda "karnas" kökünden türetilmiş ve çıkıntı anlamı kazanmış birçok kelime bulunmakla birlikte şiir örnekleri de mevcuttur (ez-Zebîdî, c. 16, s. 369). ${ }^{4}$

Celal Esat Arseven'in aktardığına göre "Fransızca'da korniş (corniche) ve Rumca'da korniza tabirleri karnas kelimesinden alınmıs olduğuna şüphe yoktur" (Arseven, 1975, c. 2, s. 965). Fakat devamında karnas kelimesinin Arapçadan değil, Yakut Türkçesinden alınmış olduğunu ve Araplar'ın kelimeyi rübâi-i mücerred olarak alıp kelimeye "mim" sesini ilave etmek suretiyle "karnaslı" anlamında "mukarnas" (çoğulu: mukarnasât) denildiğini söz konusu eder (Arseven, 1975, c. 2, s. 965).

Buna mukabil Selçuk Mülayim bu konuda Celal Esat Arseven'le aynı görüşłe

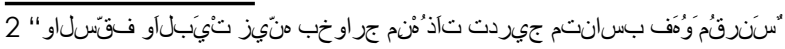

(evi veya çatıyı karnas etmek; çatıdan/evden çıkan çıkıntılarla uyumlu bir kademelendirmeyle süslemek ki; Mukarnas olur)" olarak geçmektedir.

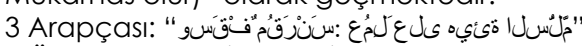

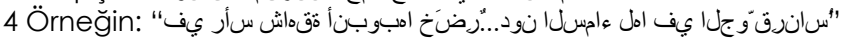




\section{arts}

değildir. Ona göre mukarnas, Redhouse'ta halk arasında kullanılmayan ilmi bir tabir olduğu belirtilen kelime Grekçe korônis (korniş) kelimesinden Arapçalaştırılarak türetilmiş olduğuna değinilerek "Batıılaşma hareketinin başlarında Batı dillerine ait ilmi terimlerin İslâmi terminolojiye çevrilmesi çalışmaları sırasında (...) Almanca karnies'ten türetilmiş olduğu düşünülebilir. Ayrıca kelimeyi türeten mimarın bunu Arapçada bir benzerinin bulunduğunu bilmeden yaptığı da söylenebilir" açıklaması yapılır (Mülâyim, s. 126). Selçuk Mülayim'in görüşüne paralel görüşler serdeden Doris Behrens-Abouseif ve Ernst Diez gibi bazı araştırmacılar mevcut olmasına karşın Celal Esad'ın yukarıda zikredilen görüşünü destekler nitelikte herhangi bir yayına şimdiye kadar rastlanılmamıştır.

Kanaatimizce İslâm medeniyetinin muhtelif dallarında olduğu gibi sanat ve mimariye ait terminolojide de Osmanlı Türkçesi ve Farsçadan Arapçaya bazı kelimeler intikal ettiği gibi benzer bir süreç yine aksi istikamette bir çizgi izlemiştir. Dolayısıyla bu tür kelimeleri, İslâm medeniyetinin müşterek terminolojisi olarak değerlendirmek gerekir. Sonuç olarak yukarıda nakledilen görüşler çerçevesinde denilebilir ki "mukarnas" kelimesi, köken itibariyle Arapça olup İslâm sanatı ve mimarisinin müştereken kullandığı bir kavram olarak bugün karşımızda durmaktadır.

Buna rağmen İslâm coğrafyasının farklı bölgelerinde mukarnas tekniği için farklı adlandırmaların mevcut olduğu da unutulmamalıdır. Örneğin Fas asıllı mimar ve sanatçılar mukarnas yerine "mukarbas" (صبرق) kelimesini kullanmaktadırlar. Bu kullanımın, İspanyolcadaki "mocárabes" kelimesinden gelmiş olabileceği uzak bir ihtimal olarak görülmemelidir. Zira "Reconquista" sonucu Endülüs'ten çıkarılan Müslümanların, sanat terminolojisi üzerindeki İspanyolca etkisini Kuzey Afrika'ya taşımış olmaları tabii karşılanmalıdır. Aynı zamanda bu mimari unsurun adı "mukarnas" şeklinde yazılması gerekirken çağdaş Arap terminolojisinde genellikle "sad" harfiyle صنان olarak yazılmaktadır. Farsça imlâda ise kelime, aslî yazılışına riayet edilerek "sin" harfiyle سنرقدمeklinde yazılır.

Bazı Arapça kaynaklarda mukarnas Dellayât olarak da isimlendirilir. Dellayât, Arapça olan tedellâ (bir çatıdan yere asılmak) filinden türetilmiş olup "istalaktit" kelimesinin Arapçasıdır. Muhtemelen Batılı araştırmacıların XIX ila XX. asırlarda İslâm eserleri hakkında yaptıkları çalışmalar Arapçaya tercüme edildiğinde sanat 
terminolojisine muttali olmayan kişilerce istalaktit kelimesine dellayât karşı̆ı̆ı verilmiş ve böylece bu terim Arap edebiyatına girmiştir. Osman İsmail'in açıklamalarına göre mukarnas ve dellayât arasında bir fark söz konusudur. Ona göre mukarnas mimarî bir unsurdur (yapısal öğe); dellayât ise mimarî bir süstür (bezeme örgesi) (İsmail, c. 2 , s. 168). Fakat böyle bir tasnife incelediğimiz diğer teliflerde rastlayamadık. Ayrıca Osman İsmail'in kendisi de görüşüne hiç bir kaynak göstermemiştir. Fakat mukarnas kelimesi söz konusu unsurun genel ismi olup dellayât/istalaktit'in ise belli bir sarkıtı mukarnas tipinin adı olduğu söylenebilir. Bu bakımdan dellayât/istalaktit ve mukarnas arasında bir fark söz konusudur. Çağdaş birçok araştırmacı tarafından kullanılan istalaktit kelimesi de mukarnas unsurunu tanıtmak için yeterli değildir.

Kanaatimizce mukarnas kelimesi istalaktit veya dellayât kelimelerinden daha kapsamlıdır. Buna göre söz konusu mimarî unsuru İslâm literatürüne uygun müşterek bir isimle adlandırılacak olunursa buna hiç tereddüt etmeden mukarnas denilmesi gerekecektir. Çünkü bu isim sanat terminolojimize ait hayli kadim bir isimlendirme olmasının yanı sıra İsıâm coğrafyasının muhtelif bölgelerinde herkesin anlayabileceği bir terim olma hüviyetine de sahiptir.

Kimi zaman geçiş öğesi olarak kimi zaman da bezeme ögesi olarak kullanılan mukarnasın bize ulaşan en eski tanımı el-Kâşî’ye aittir. el-Kâşî mukarnası şöyle tanımlamaktadır:

\begin{abstract}
"Mukarnas, kenarlar ve yüzeyler intiva eden merdivenli bir çatıdan ibarettir. Her kenarı yanındaki kenarla dik, yarı dik veya hem dik hem yarısının toplami olan bir açı ve yahut bir başka açıyla kesişir ve tüm bu kenarlar ufuk çizgisiyle paralel varsayılan bir yüzeye diktir. Bu kenarların üzerinde, ufuk çizgisine paralel olmayan bir veya iki düz veya eğimli bir yüzey yer alır. Ónlar da mukarnasın çatısıdır. Bu kenarlara çatısılyla birlikte beyt (hücre) denir. Ayrıca, tabanları ufuk çizgisine paralel bir yüzeyde bulunan ve yan yana sıralanan beytlerin birliğine tabaka denir. Tabandaki en büyük kenarın miktarına ise mukarnasın mikyas'ı (ölçüsü) denir. Gördügümmüz mukarnasların türleri ise dört çeşittir: Sâzec (Basit mukarnas) veya inşaatçıların adlandırdığı gibi birûminber, mutayyan (çamurlu mukarnas), kavisli mukarnas ve şirâzí mukarnas"s ( elKâşî, s. 180).
\end{abstract}

El-Kâşî' den sonra mukarnasın ne olduğuna dair çok sayıda tanım yapılmıştır. Bunlar içerisinde Celal Esad Arseven'in şu tanımını zikretmemiz yerinde olacaktır: "Bir satıhtan diğer bir satha veya girgin bir kısımdan taşkın bir kısma geçerken, istinat veya tezyinat maksadıyla kullanılan menşurî (prizmatik) parçalara mukarnas denmektedir" (Arseven, 1975, c. 2, s. 953).

5 Makram HADDAD tarafindan Arapça'dan Türkçe'ye çevrilmiştir. 


\section{arts}

\section{MUKARNASIN MENŞEi}

Mukarnasın menşei ile ilgili kanaatimizi belirtirken günümüze ulaşmış ve araştırmacılar arasında tartışma konusu olan en eski örnekleri ele alıp incelemeleri şu şekilde yapmaya çalışacağız:

\section{a) Arap Ata Türbesi}

Karahanlı dönemine ait en eski türbelerden biri olup bugünkü Özbekistan'ın Tim şehrinde 978 yılında inşa edilmiş bir türbedir. Bu türbenin kubbesi kare planlı bir kasnak üzerine oturtulmuş ve dört köşesinde ilkel mukarnas diyebileceğimiz birer tromp yerleştirilmiştir (Görsel 1). Bu tromplar, üst kısmı niş şeklinde bir birim, alt kısmı ise el-Kâşi mukarnası diye bilinen mukarnas hücresinin biçiminde olan üç birim olarak iki tabakadan ibarettir. Bu düzen, bildiğimiz mukarnas yapısına çok benzeyen bir düzendir. Bu örnek, beyitlerinin mevcut örnekler arasında en basit olanı olduğu için mukarnasın ilk örneklerine yakın olduğunu söylemek mümkündür.

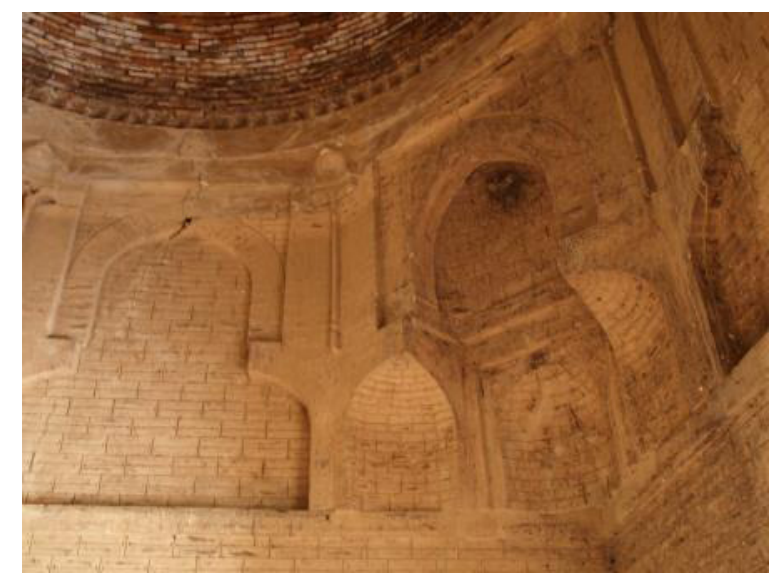

Görsel 1. Arap Ata Türbesi (Okuryazarım)

\section{b) Kümbed-i Âlî}

İsfahan'ın güneyinde yer alan Abarkuh şehrinde 1056 yllında inşa edilmiştir. Büyük Selçuklu mezar yapıları arasında en eski tarihli olanıdır. Bu kümbetin sekiz köşeli gövdesinin dış duvarının üst kısmında üç tabakalı mukarnaslı bir kuşak yer almaktadır (Görsel 2). Bu örnekteki mukarnas hücreleri az önce bahsettiğimiz Arap Atâ Türbesi'ndeki mukarnas birimlerine tamamen benzemekte olup Orta Asya ve İran' da bundan sonraki tarihlerde göreceğimiz mukarnas örneklerine de benzemektedir. Arap Atâ Türbesi'nin mukarnasının aksine bu örnek birçok birim ve birden fazla tabakadan ibarettir ve onun önemi bu özelliklerinden kaynaklanmaktadır. 6 https://okuryazarim.com/karahanli-sanati/, Son erişim tarihi: 17/07/2020. 


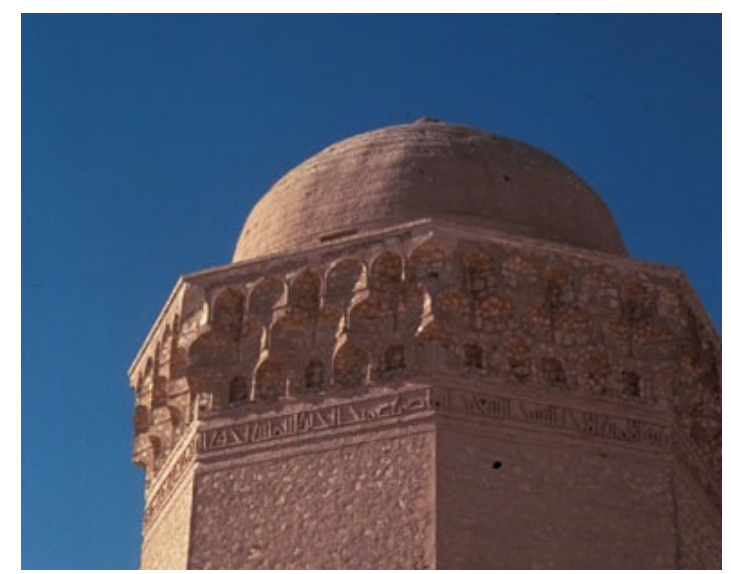

Görsel 2. Kümbed-i Âlî (Okuryazarım)

\section{c) İsfahan Cuma Camii}

Büyük Selçuklu yapısı olan bu bina XI. ašın sonlarında inşa edilmiş olup farklı tarihlere ait çeşitli ilaveler görmüşłür. Bu caminin farklı bölümlerinde ebadı farkı olan mukarnas örnekleri mevcuttur. Caminin ibadet mekanındaki ana kubbenin mukarnaslı tromplarının birimleri Arap Atâ Türbesi'ni hatırlatır (Görsel 3). Avlusunun XII. asırda eklenmiş (Çoruhlu, s. 504-506) eyvanlarındaki mukarnasların hücreleri daha eski tarihlere ait mukarnasılı trompların hücrelerinden daha gelişmiş bir vaziyettedir.

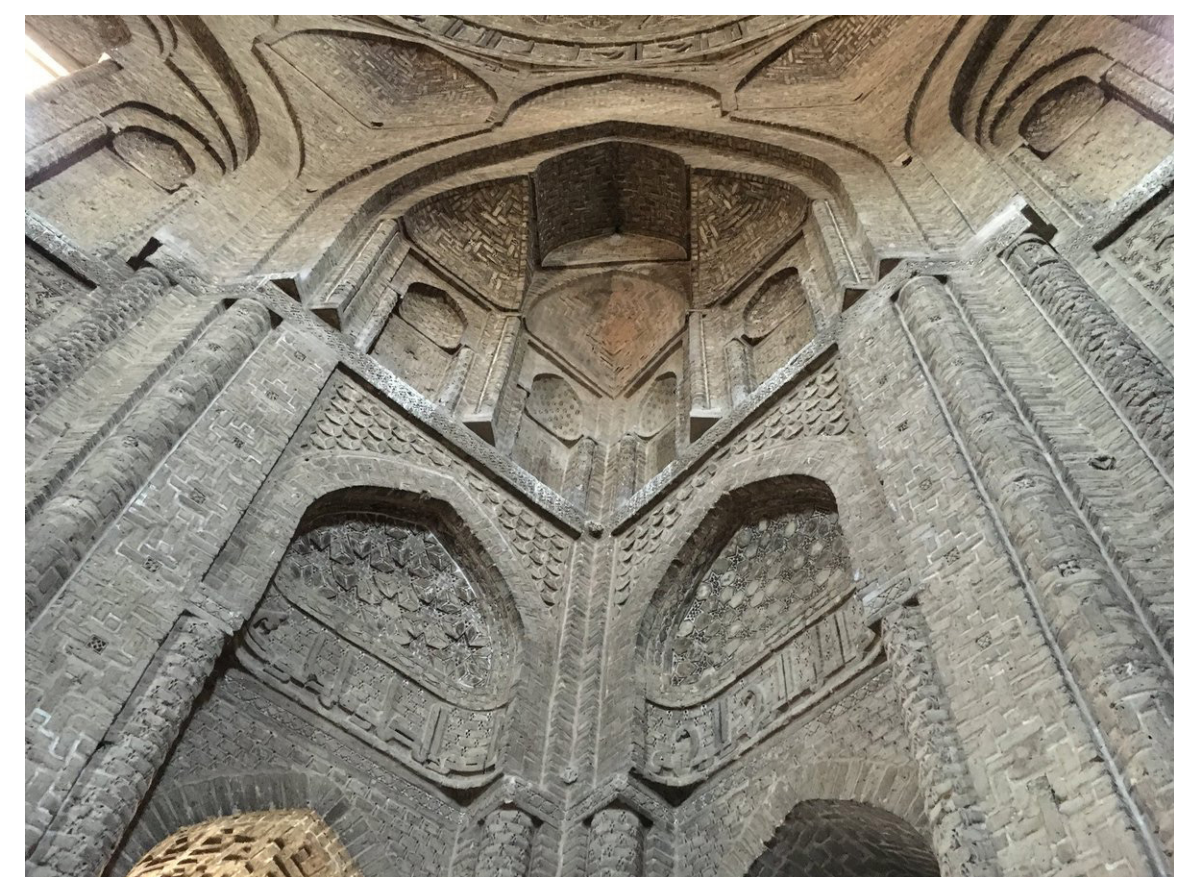

Görsel 3. İsahan Camii'nin Ibadet Mekanındaki Ana Kubbenin Mukarnasılı Tromplarından Bir Detay ( Mustafa Furkan Özren)

7 https://okuryazarim.com/kumbet-i-ali/, Son erişim tarihi: 17/07/2020. 


\section{d) İmam Dur Türbesi}

Samerra civarında XI. yüzyılın sonunda inşa edilmiş ve İslâm dünyasında yapılmış ilk mukarnaslı kubbe addedilir. Bu kubbenin beş tabakalı mukarnasının birimleri, İran ve Orta Asya'daki büyük Selçuklu ve bir önceki dönemlerde yapılan mukarnasların birimlerine benzemektedir. Malzeme olarak da yine İran ve Maveraünnehir mukarnaslarında olduğu gibi alçı kullanılmıştır (Görsel 4-5).

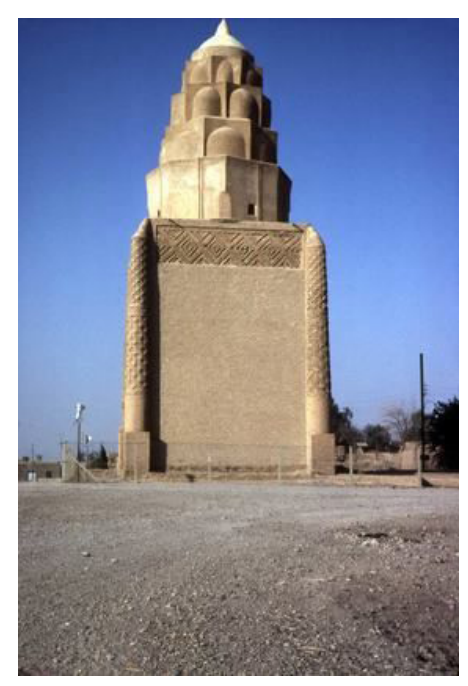

Görsel 4. Imam Dur Türbesi (Archnet) ${ }^{8}$

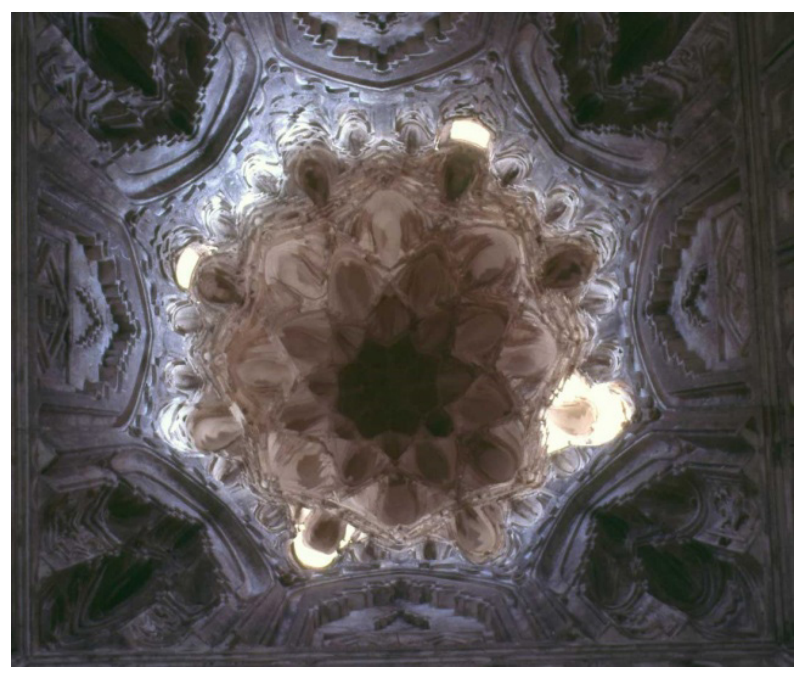

Görsel 5. Imam Dur Türbesi; Kubbenin Içi (Archnet) ${ }^{9}$

\section{e) El-Cüyüşî Camii}

Mısır'da Ermeni asıllı Emirü'l Cüyûş Bedr el-Cemali tarafından inşa edildiği için Cami'ü'I-Cüyûş̂̂ diye isimlendirilmiştir. Kitabesine göre 1085 yılında inşa edilmiştir. Bu camide Tunus'taki Kayrevan Camii'nin minaresine benzeyen kare planlı ve iki 8 https://archnet.org/sites/3838, Son erişim tarihi: 17/07/2020. 9 https://archnet.org/sites/3838, Son erişim tarihi: 17/07/2020. 
katlı bir minare yer alır. Ayrıca minarenin gövdesinin üst kenarında nadir rastlanan mukarnaslı bir korniş bulunmaktadır (Görsel 6). Bu mukarnas iki tabakalı olup hücreleri de Kümbeti Ali mukarnasının hücrelerine benzemektedir.

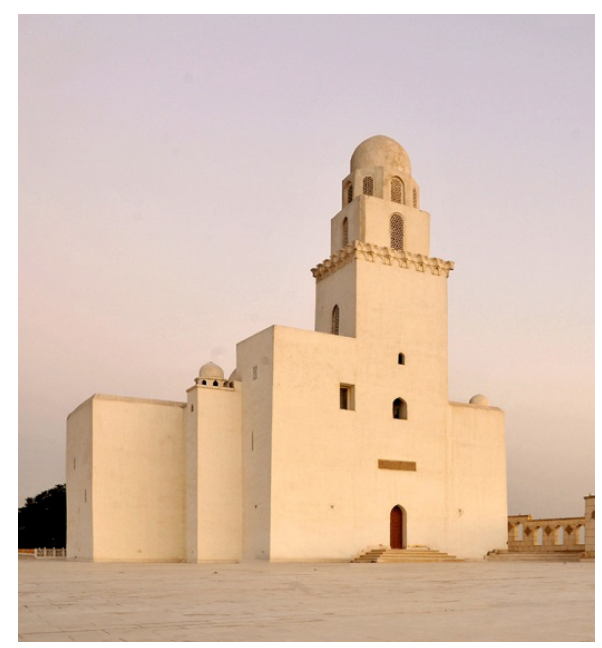

Görsel 6. El-Cüyüşî Camii'nin Minaresi (Faiz-E-Haakimi) ${ }^{10}$

\section{f) Murabıtlar Kubbesi}

Yanındaki Ali bin Yusuf camisi için abdest alma yeri olduğu düşünülen bu kubbe, Ali bin Yusuf (1 107- 1 143) zamanında Marakeş şehrinde inşa edilmiştir. Nebâî süslemelerle oyulmuş sekizgen şeklinde olan bu kubbenin dört köşesinde birer mukarnası küçük kubbe yer almaktadır. Bu kubbelerin mukarnası iki tabakalı olup tepesi ortadaki büyük kubbede olduğu gibi sekiz dilimlidir (Görsel 7).

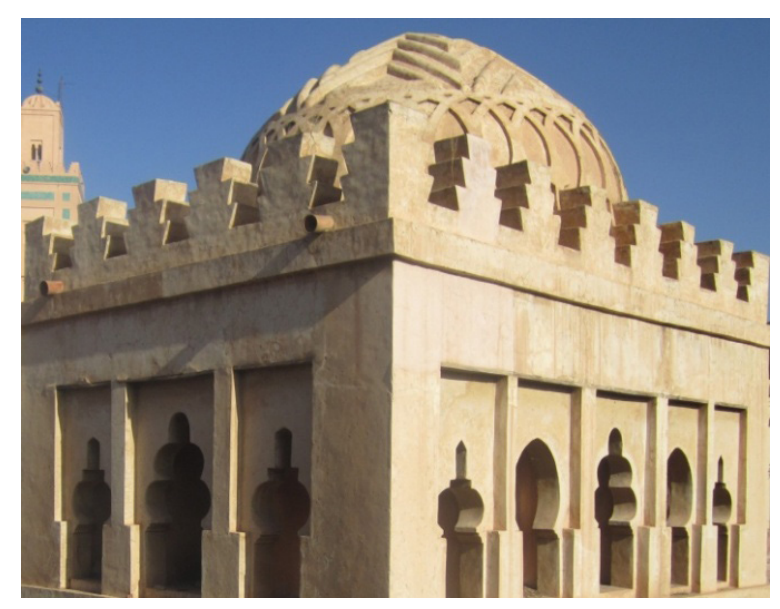

Görsel 7. Murabıtlar Kubbesi 


\section{arts}

\section{g) Kal'atü Beni Hammâd}

Cezayir'de XI. yüzyılda Berberîler tarafından kurulan bir kale-şehirdir. Burada yer alan Kasrü'l Bahr denilen mevkide pişmiş topraktan mamul merdivenli şekilde birbirine yapıştııımış piramidal bir hale gelmiş paralel yüzlerden teşekkül eder (Görsel 8).

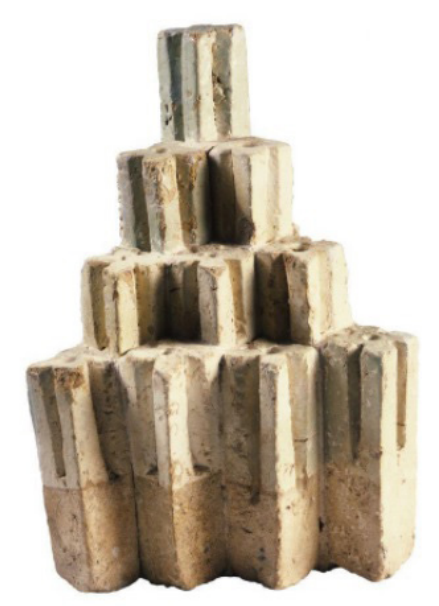

Görsel 8. Benî Hammâd Kalesinde Bulunan Bir Unsur (Houria Cherid)"1

Bu örnek birçok araştırmacı tarafından Mağrib'deki mukarnasın ilk örneği olarak kabul edilmektedir. Birçok sebepten ötürü bunun bir mukarnas olabileceği konusunda şüphelerimiz bulunmaktadır. Hatta bu unsurun başka bir mahiyete sahip olduğunu düşünmekteyiz. Zira bilebildiğimiz kadarıyla başka bir yapıda böyle bir şekle mukarnas olarak ne bu dönemde ne de farklı tarihli dönemlerde rastlanılmıştır. Buradaki de duvarların köşelerinde yer alması ve en az iki veya dört tanesi bulunması gerekirken tek olarak bize ulaşmış ve arkeologlar tarafından duvara yapışık değil de enkaz altında bulunmuştur. Ayrıca malzeme olarak da Mağrib bölgesindeki mukarnas örneklerinden ayrılmaktadır. Tahminimizce bu şeklin mukarnas olduğunu ilk söyleyen kişi Fransız asker De Beylié (1849-1910) olup bunu "La Kalaades BeniHammad, une capitale berbère de l'Afrique du Nord au Xle siècle" (De Beylié: ${ }^{258)}$ adı kitabında nakletmektedir. Sonraki araşıımacılar da bu bilgiyi benimsemişlerdir.

\section{MUKARNASIN MAŞRIKTAN ISLÂM COĞRAFYASINA YAYILMASI}

İslâm coğrafyasındaki ilk mukarnas örneklerini baktığımızda mukarnasın doğudan batıya doğru bir güzergâh takip ettiği görülür. Günümüze kadar ulaşabilmiş bu ilk mukarnaslar arasında uzun bir zaman yokken coğrafi bakımından aralarındaki mesafe kısa sayılmaz. Bu da dönemin siyasi ve sosyal şartlarıyla ilişkili bir husustur. 11 http://islamicart.museumwnf.org/database_item.php?id=object;ISL;dz;Mus01;16;en, Son erişim tarihi:17/07/2020. 
Şöyle ki, geniş İslâm coğrafyasının farklı ve birbirine uzak bölgeleri arasındaki kültürel, bilimsel ve sanatsal faaliyetler hızlı bir geçişkenlik göstermekteydi. İslâm 'ın ortaya çıkışından Osmanlı İmparatorluğu'nun yıkııısına kadar bu durum sürüp gitmiştir. Bilim adamları, zanaatkârlar, seyyahlar ve her kesimden insanlar İslâm coğrafyasının farklı bölgeleri arasında vizesiz yolculuk yapabilmekte, hatta devamlı olarak bir bölgede ikamet edebilmekteydiler. Nitekim herhangi bir bölgede mevcut olan veya icat edilmiş olan bilgi, birikim veya teknik cinsinden maarif, Müslümanların diğer coğrafyalarına kolayca geçebilmekteydi. İşte mukarnas da bu şekilde ortaya çıkıp hızlı bir şekilde yayılarak İsı̂m dünyasının öbür ucundaki diğer bölgelere ulaşmıştır.

Yukarıdaki listede sıralanan mukarnasın ilk örnekleri ve tarihlerine bakılınca ilk örneklerin ilk olarak doğuda zuhur edip batıya doğru ilerlediği görülür. Fakat mukarnasın; malzemesi, teknikleri ve uygulandığı mimari kısımlara bakılınca durum değişir. Mesela ilk mukarnaslı tromp Arap Atâ Türbesi'ndeki iken ilk mukarnaslı kubbenin İmam Dur Türbesi' nin kubbesi olduğu kabul edilmektedir. Yani Orta Asya'da ortaya çıkan mukarnas diğer coğrafyalara intikal ettiğinde farklı çevrelerden etkilenerek yeni teknikler ve vazifeler kazanıp farkı tiplerin teşekkülüne yol açmıştır.

Bu bağlamda mukarnasın doğudan batıya yaptığı tahmin edilen yolculuğun haritasını belirtecek olursak şöyle söyleyebiliriz:

Illk örnekleri göz önünde bulundurulduğunda mukarnasın Mâverâünnehir bölgesinde ortaya çıktığını ifade edebiliriz. Böylece ilk örnek, bir Türk-İslâm hanedanı olan Karahanlılar zamanına tarihlenmiş olur. Akabinde Maveraünnehir'e komşu olan İran bölgesine geçmiş olmalı ki, özellikle XI. asırda tüm İran'da, hatta Irak'ın bazı yerlerinde inşa edilmiş birçok mimari eserlerde rastlanabilmektedir. Kanaatimizce mukarnasın Irak coğrafyasına ulaşması, onuncu asırda kurulan ve eski Sâsânî imparatorlarının soyundan gelmiş olduklarını iddia eden Büveyhilerin hem Irak hem de İran bölgelerinde hüküm sürmesinin bir sonucudur. Zira o dönemde Irak ve İran bölgeleri arasındaki kültürel, bilimsel ve mezhepsel bağlar bir hayli güçlü durumdaydı.

Orta Asya, İran ve Irak arasındaki coğrafî yakınlıktan dolayı mukarnasın bu üç bölgede yakın tarihlerde zuhur etmesi anlaşılabilen bir durumdur. Fakat erken bir tarihte Mısır'da zuhur etmiş olması dikkat çekicidir. Bu hususta, Crewsell'in bir 
tesbiti önem arz eder. Ona göre Mısır'daki Ermeni asıllı Emirü'l Cüyûş Bedr el-Cemali tarafından inşa edilen el-Cüyûşî Camii'nin minaresindeki mukarnaslar, Ermeniler tarafında yapılmıştır. Buna göre ilk önce İran'daki Kümbet-i Ali 1056 yılında inşa edilir, ondan sonra 1072 senesinde Ani'deki Ebu'l-Menuçehr Camii inşa edilmiş ve en son Mısır' daki el-Cüyûşî Camii 1085 yılında kurulur. Böylece Ermeni zanaatkârlar, mukarnasın Ani'den Mısır'a ulaşmasını sağlamış olurlar (Creswell, c. 1, s. 159).

Daha önce zikredildiği gibi Beni Hammad kalesinde bulunmuş seramikten yapılmış olan paralelyüzlüler, tezyinî bir unsur olsa da mukarnas olma ihtimali çok düşüktür. Bu kanaatin sebebi de yukarıda açıklanmıştır. Ayrıca, Mağrib'de ilk mukarnaslar Beni Hammad kalesinin inşa tarihine yakın olmakla beraber ${ }^{12}$ yapı olarak ona hiç benzememektedir. Evrimsel bir şekilde düşünsek de bu kalede bulunmuş paralelyüzler ile Mağrib' de ilk mukarnaslardan sayabileceğimiz Murabıtlar kubbesindeki köşe mukarnasları (Görsel 9) arasında hiçbir benzerlik bulunmamakta; hatta ikisinin arasında bağlayıcı bir halka olabilen ortak bir unsur dahi mevcut değildir. Keza XI. asır ve sonrasında Sicilya ve Güney İtalya'da inşa edilmiş mukarnaslı yapılarda da paralelyüzlü mukarnaslara rastlanmamaktadır.

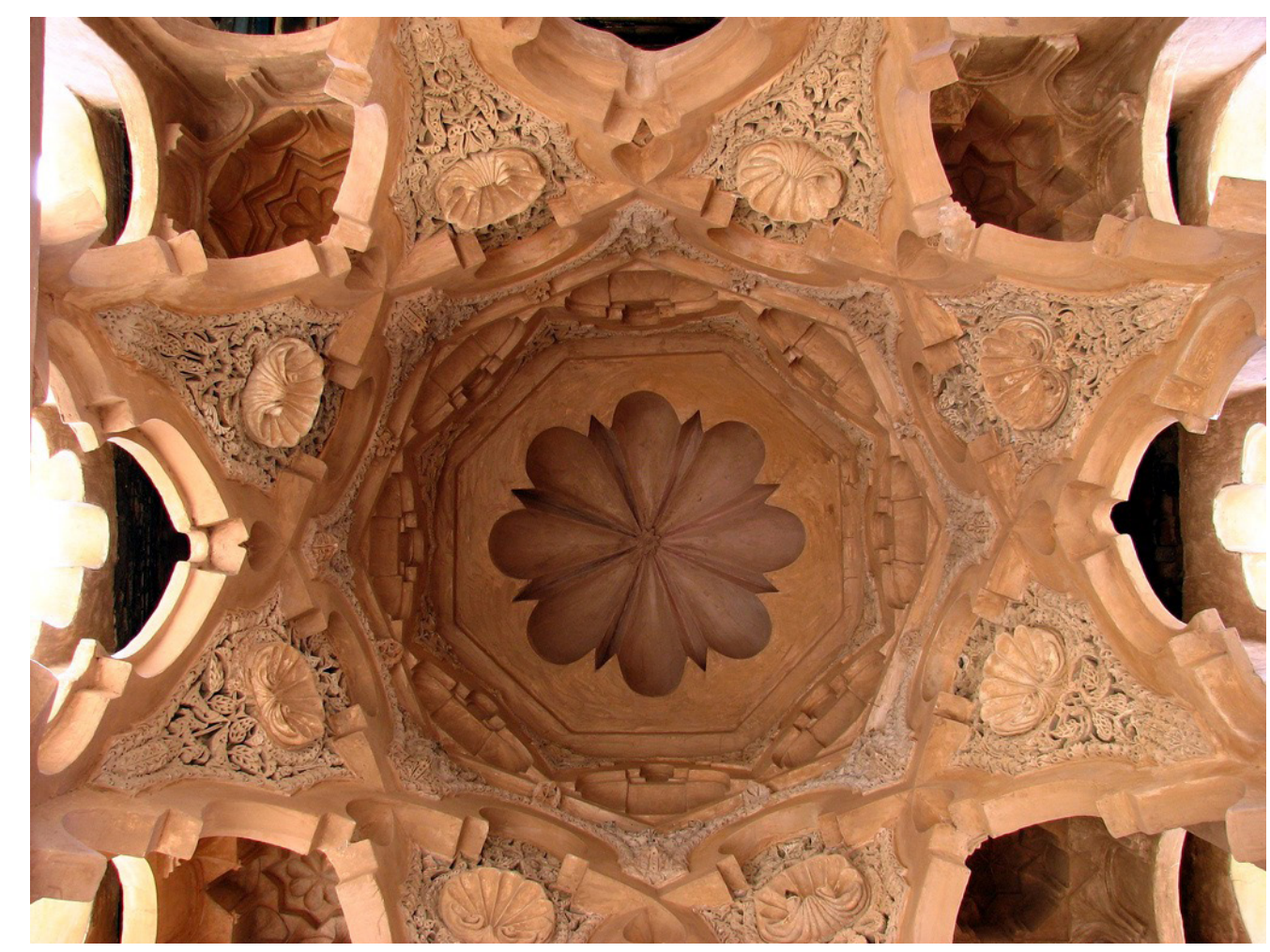

Görsel 9. Murabıtlar Kubbesi'nin Içi

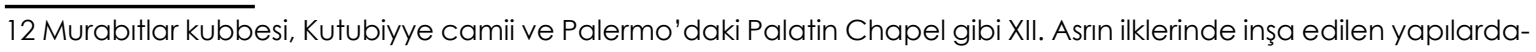
ki mukarnaslar Beni Hammad kalesindeki unsurlara hiç benzememektedir. 
Bununla beraber, Asım Muhammed Rızık gibi bazı arkeologlar Kayravan Camii'nin mihrap kubbesinde primitif bir mukarnas bulunduğunu belirtirler (Rızık, s. 294). Fakat kanaatimizce bu kubbede mukarnas diyebileceğimiz bir unsur bulunmadığı gibi kubbe altında dilimli tromplar ve kemerler dışında mukarnasa benzeyen başka bir unsur dahi yoktur. Tahminimizce bu tip görüşler, mukarnas diyebileceğimiz unsurun mahiyetini belirtmemiş olmaktan kaynaklanıyor. Çünkü Asım Rızık dışında Ferid Şafî̃ ve Muhammed Afifî gibi bazı arkeologlar da kubbe kasnaklarının köşelerindeki trompları mukarnasın bir birimi olarak saymaktadırlar (Afifî, s. 285; Şafi, s. 31).

Buna göre mukarnasın Kuzey Afrika'da ilk görüldüğü dönem dikkate alındığında Fatımîler asrında (909-1 171) Mısır'dan Kuzey Afrika'ya bir şekilde geçmiş olduğu tahmin edilebilir. Fatımîler, başkentini 973 senesinde Tunus'tan Kahire'ye taşımışlardır; fakat Kuzey Afrika'daki hâkimiyetleri el-Muiz bin Bâdîs' in 1045 senesinde Abbasilere tabi olduklarını ilan edene dek devam etmiştir (Seyyid, c. 12, s. 228-237). Bu hadiseden dolayı Fatımîler, 1058 yılından itibaren Beni Hilâl kabilelerinin Mısır'dan Kuzey Afrika'ya geçmesini teşvik etmişlerdir. Daha sonra 1108 ile 1116 seneleri arasında (Yahya bin Tamim zamanında) başkenti Kayravan'dan Mahdiyye'ye taşıyan Zîrîlerin tabiliği tekrardan Mısır'daki Fatımîlere ilan edilmiştir (Idris, c. 1, s. 357).

Vardığımız kanaati özetleyecek olursak mukarnasın ortaya çıktığı ilk yer Orta Asya olup kısa sürede tüm İslâm dünyasında kullanım alanı genişlemiş ve zamanla farklı karakterler kazanarak yeni şekil ve teknikler ortaya çıkmışłır. Fakat mukarnasın Mağrib' deki ilk zuhuruna dair çoğu görüşler her hangi bir arkeolojik bulgu veya tarihî bir gerçeğe dayanmadığı için bu konuyla ilgili daha ayrıntıı bir incelemeye intiyaç duyulmaktadır.

\section{MAĞRIBÎ MUKARNASIN ZUHURU}

Yukarıda ifade edildiği gibi mukarnasın, İslâm coğrafyasının doğudaki en uzak noktalarında doğup bir veya bir buçuk asır içerisinde coğrafyanın uzak batı kıyılarında zuhur etmesi, hızlı bir şekilde gelişip doğudakinden farklı olarak kendine özel bir sistem kazanması ve o bölgenin mimarlığının alamet-i fârikası olmasından 


\section{$\operatorname{arts}=$}

dolayı, Mağrib coğrafyasında ilk zuhuruna dair farklı teoriler ortaya çıkmıştır. Konu ile ilgili teorilerin üç gruba ayrıması mümkündür. Oleg Grabar başta olmak üzere birinci grubun tezine göre Mağribi mukarnas, Maşrıkî mukarnasla paralel olarak ve iki tarzın arasında hiçbir etkileşme olmadan ortaya çıkmış (Grabar, 1978, s. 175). İkinci grubun teorisine göre ise Mağribi mukarnasın ilk çıkışı kuzey Afrika'da değil de Endülüs'ün Almeria şehrinde vuku bulup Kuzey Afrika bölgesine geçmiş. Bu teorinin sahibi İspanyol tarihçi Jacinto Bosch Vilá'dır (Maldonado, 2010, c. 4, s. 1878; Vilá, 1977, c. 8, s.139-160). Üçüncü teze göre ise mukarnas, doğuda doğup hızlı bir şekilde tüm İslâm coğrafyasına yayılmış ve Mağrib bölgesinin doğu kapısından girip Endülüs'e ulaşmıştır. Bu üç tez yakından incelendiğinde şunlar söylenebilir:

Illk teoriye göre mukarnas, İslâm coğrafyasında eşzamanlı olarak hem İran'ın kuzey doğusunda hem de Afrika'nın kuzey ortasında iki bölgenin arasında temas noktası olmadan ortaya çıkmıştır. Fakat bu görüş, bir kaç sebepten dolayı tatminkâr değildir. Zira ilkel mukarnasın en erken örnekleri İran ve Orta Asya' da görülmektedir. ${ }^{13}$ Kuzey Afrika ve Endülüs'teki ilk zuhuru ile bu ilkel mukarnasların arasındaki süre bir buçuk asırdan fazladır. Yani bu iki tip mukarnasın zuhuru eşzamanlı değildir. Ayrıca, mukarnas gibi karmaşık bir unsurun "tesadüfen" iki farklı bölgede, yakın tarihlerde ve aynı görünüşle ortaya çıkması pek mantıklı değildir. En azından rastlanması çok ender bir durumdur. Buna binaen bu görüşün isabetli olma intimali çok düşük olarak değerlendirilmiştir.

İkinci teze gelince, Jacinto Bosch Vilá'ya göre mukarnasın ilk zuhuru İslâm coğrafyanın doğu tarafında olup Mağrib bölgesine ilk girişi ıfrîkiyye tarafından değil de Endülüs'ün doğu kıyısı ve tam olarak Almeria limanı üzerinden gerçekleşmiştir. Bu tez de coğrafyacı ve tarihçi olan el-Uzrî el-Endelüsî'nin (1003-1085) Tarsi'ü'l Ehbâr adlı eserinde geçen mukarnas (سنرقم) kelimesine dayanmaktadır (el-Uzrî, s. 85). ${ }^{14}$ Şöyle ki adı geçen eserde, Almeria (Endülüs) şehrinde 1054 (Muhammed bin Ma'n'ın vilayetin başına geldiği tarih) ile 1085 (el-Uzrî'nin vefat tarihi) seneleri arasında inşa

13 Grabar'ın bu görüşü, Beni Hammâd kalesindeki erken tarihe (1007) ait unsurun mukarnas olduğuna dayanmaktadır. Fakat daha önce zikredildiği gibi bu unsurun mukarnas olduğunu ispatlayan ciddi bir delile ulaşılamamıştır. Böylece de, Mağrib bölgesinde günümüze ulaşmış en erken mukarnas örneği, Murabıtlar kubbesinin dört köşelerindeki birer küçük mukarnaslı kubbedir. Bu yapı ile İran ve Orta Asya'nın ilk mukarnas denemelerin arasında da bir buçuk asırdan fazla olan bir müddet vardır.

14 Tarsi '̈̈'l Ehbâr adlı kitapta, Almeria'nın valisi olan Muhammed bin Ma'n'ın (dönemi 446/1054 yllında başlamış) yaptırdığı sarayın içerisinde bulunan bir salon (Meclis) anlatılırken, şu ifadeler kullanılımıştır:

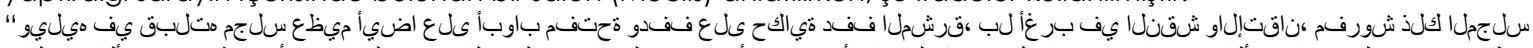

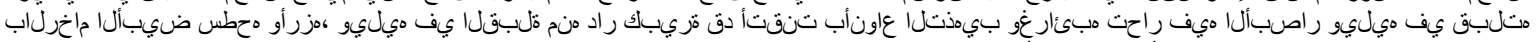
" 
edilmiş bir sarayın müştemilatının ayrıntıları anlatılmıştır. Anlatırken de o sarayda bulunan bir salonun iç mekânı "...altınla kaplanmış müzeyyen raflarla mukarnaslı bir meclis (salon)..." şeklinde tavsif edilmiştir. Böyle bir yapı günümüze kadar ulaşmamış olsa da Endülüs eserleri uzmanı olan İspanyol tarihçisi Basilio Pavón Maldonado da bu teorinin muteber olduğunu ima eder (Maldonado, c. 4, s.185).

Endülüslü sanatkârların Kuzey Afrika'daki İslâm sanatının tekâmülünde oynadığı rol göz önünde bulundurulursa bu görüş mantıklı addedilebilir. Ancak yine de bir iki tenkidimiz söz konusu olabilir:

Günümüzde, metinde anlatılan yapıya benzeyen bir esere rastlanmamakla beraber "mukarnas" kelimesinden kastedilen şey, bildiğimiz mimari unsuru mu yoksa sözlükteki "çıkıntılı satıh" anlamına gelen kelime mi diye kesin bir kanaate varmak kolay bir şey değildir. Üstelik "raflarla mukarnaslı" ibaresindeki raflar (فوُفُر) ifadesi de asıl anlamına'5 değil de "mukarnasın merdivenli birimlerin her biri" anlamında kullanılmış olmalıdır. Ayrıca günümüze ulaşmış mukarnas eserlere bakııırsa dikdörtgen şeklinde olan mukarnasın ilk örnekleri, Karaviyyîn Camii'nin orta nefinde bulunan tonoz (XII. asrın ilk yarısı) ve Palermo'da 1180 yılında inşa edilmiş Cappella Palatina Kilisesi'nin orta nefini örten ahşaplı mukarnastır. Almeria' da bu kadar erken bir tarihte (1054 ile 1085 arası) mukarnaslı bir çatıyla örtülen bir salonun bulunması da pek mantıklı gözükmemektedir. ${ }^{16}$ Çünkü -günümüzde bilinen örneklere nispeten- bütün İslâm coğrafyasında bu tarihte inşa edilmiş mukarnas örnekleri hala ilkel bir vaziyette olup daha çok tonoz bingiler ve basit kuşaklar gibi yerlerde bulunmaktadır. Buna binaen söz konusu metindeki "mukarnas" ifadesi büyük ihtimalle çıkıntılı birimlere sahip başka bir örtü sistemi için kullanımıştır. Kurtuba Ulu Camii'ndeki bazı neflerin çıkıntılı ahşap örtüleri buna örnektir (Görsel 10). ${ }^{17}$ Bu tarz çatılar, hem salon gibi geniş bir alanı örtme niteliğine sahip, hem de ahşaplı olduğu için alıın kaplamalı tezyînâta

\section{kâbildir.}

15 Türkçe'ye de geçmiş bu kelime, genellikle tahtadan ya da metalden yapılmış, bir duvara ya da bir dolabın içine

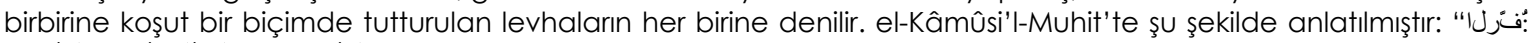

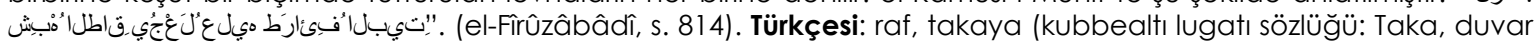
içine yapılmış küçük, kapaksız dolap) benzeyen üstüne evin eşyalarını koymaya yarayan bir şeydir.

16 Salonun çatısı mukarnaslı diye metinde açıkça zikredilmemişse de anlaşılan mana öyle olmalıdır. Zira müellif, aynı salonu vasıf ederken "beyaz mermerle mefruş (serilmiş) ve oyulmuş mermerle yanlardan kaplanmış" şeklinde döşeme ve duvarları da açıkça zikretmeden onların mermerle kaplamalı olduklarını anlatmıştı. Ayrıca "mukarnaslı Salon" (سنرقم سلجم) ifadesinden salonun üstü mukarnaslı kubbeyle örtülü diye bir ihtimal da çok düşüktür. Çünkü durum öyle olsaydı, direk "mukarnaslı kubbe" derdi. Öylece "mukarnaslı salon (Meclis)" ifadesinden anlaşılabilen mana; "üstü mukarnasla örtülenmiş" olmalıdır. Buna göre de o kadar erken bir tarihte bir salonun tamamı mukarnasla örtülü olması, İsıâm coğrafyasında bulunan mukarnas örneklerinin kronolojik gelişimiyle uyuşmamaktadır.

17 Yukarıda bahsedildiği gibi mülükü'† Tevâif zamanında çıkan bu tarz çatılar, Müdeccen döneminde gelişip çokça rastlanmaya başlar ve farklı şekilleri kazanır. Müdeccen döneminin en güzel örneklerinden Zargoza şehrindeki Aljaferia sarayın II. Ferdinand zamanında 1493 yılında inşa edilen taht salonunun üstünü örten altın rengiyle süslenmiş intişamlı çatıdır. (Gualis, s. 91) 


\section{arts}

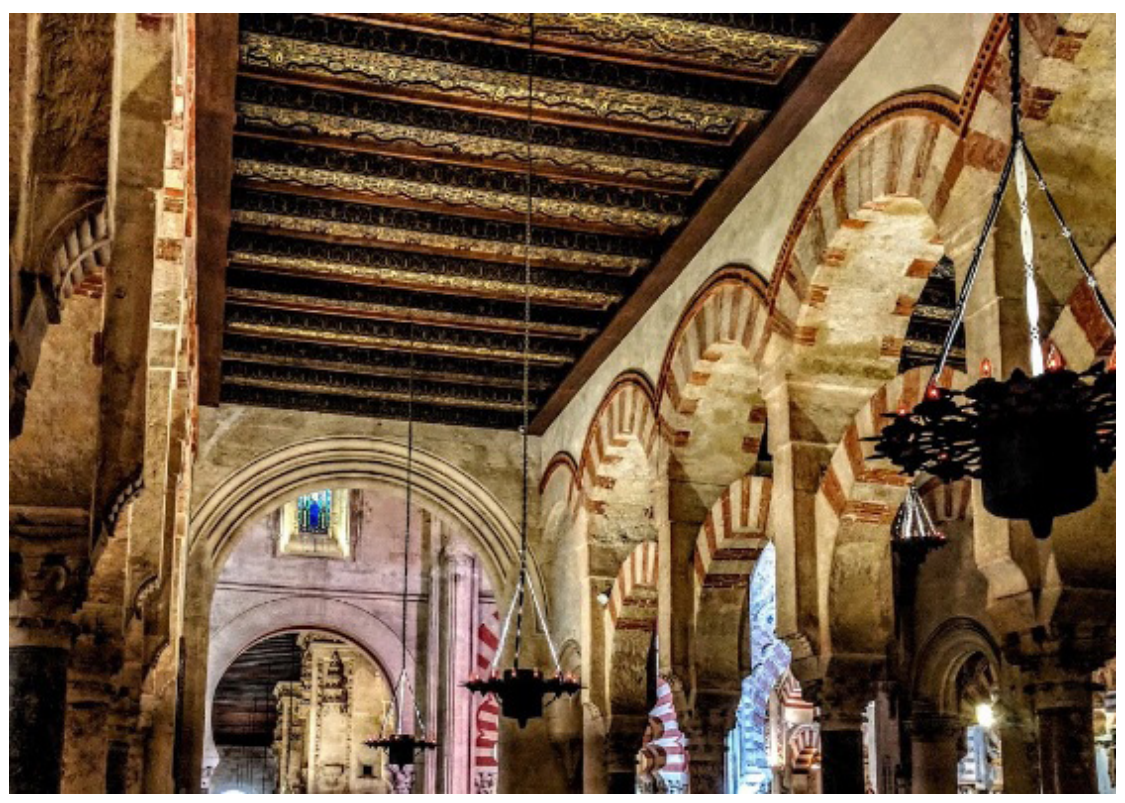

Görsel 10. Kurtuba Ulu Camii'nde Bir Sahnın Çatısı

Maldonado'ya göre de bu tarz örtülere XI. ve XII. asırdan itibaren Toledo, Malaga, Gırnata ve Almeria' da rastlanmaya başlar (Maldonado, c. 1, s. 154). Buna göre Almeria şehrinin XI. yüzyılında bu tarz örtü sistemlerini tanımış olması da zikredilen intimali güçlendirmektedir.

Söz konusu metinle ilgili de, Kurtuba Ulu Camii'ndeki çıkıntılı ahşap örtüler yere indirilip yan duvara yerleştirilirse çok raflı açık bir dolap olarak kullanılabilirler. Şöyle ki el-Uzrî'nin Almeria'daki salonun çatısını anlatmak için kullandığı ifadeleri bu örtü sistemi için kullanmak bir hayli isabetli olur. Yani "[çatısı] raflarla mukarnaslı (çıkıntılı), müzeyyen ve altınla kaplanmış müthiş bir salon".

Ayrıca SâgânîRadıyyüddin'nin (ö650/1252) el- $\square$ Ubâbü'z-zâhir adlısözlüğünde

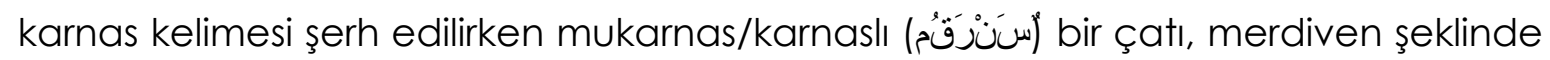
yapılmış bir çatı anlamına geldiğinin ifade edilmesi göz önünde bulundurulursa yukarıda söz konusu edilen bu faraziye bir kat daha güçlenmiş olur (es-Sâganî, c. 3, s. 408).

Almeria salonunun örtüsünün mukarnas sistemli olduğuna dair görüşü kabul etmek için o eserden kalmış maddî bir delile intiyaç duymaktayız veya en azında o tarihe yakın benzer bir unsur bulmalıyız. Böylece bu tezi kabul etmek icin yeterli delilin olmadıgı gorülmektedir. 
Üçüncü görüş ise günümüze kadar ulaşmış olan mukarnas örneklerinin kronolojik çizgisini takip ederek ortaya çıkmıştır. Bu çizgiye göre mukarnasın Mağrib' de ilk zuhuru Mısır' daki ortaya çıkışından daha sonra vuku bulmuştur. Buna göre mukarnasın Mağrib bölgesine geçmesinin vasıtası, o dönemlerde Fatımîlerin hâkimiyeti altında olan Mısır olmalıdır. Bu görüşü de Creswell, Georges Marcais ve Torres Balbás gibi sanat tarihçiler tercih etmişlerdir. Creswell'e göre de Mağrib' 'e giren ilk mukarnas örnekleri, kubbelere geçiş unsurlar şeklindeydiler. Fakat Mağrib'deki bu mukarnaslı geçiş unsurların Mısır'dakinden daha gelişmiş olduğuna işaret edip bu gelişmelerin yerli ustaların kaynağı bilinmeyen tekniklerinden vuku bulduğunu belirtir.

Bu son görüş -kanaatimizce- en mantıklı tez olmakla beraber Mağrib'in en eski mukarnas örneği olan Murabıtlar kubbesinden daha eski bir tarihe ait bir mukarnas bulunmasına dair tahminlerimiz de vardır. Bunun sebebi de mezkûr olan kubbenin mukarnaslarındaki birimlerin Maşrıkî mukarnasın sisteminden büyük bir farklılık göstermesidir. Murabıtların birçok eserinin Muvahhitlerin gelmesiyle tahrip edilmiş olduğu göz önünde bulundurulursa Mağribi mukarnasın tespit edilebilen ilk örneği olan Murabıtlar kubbesinin mukarnasından daha az gelişmiş veya Maşrıkî olanlara daha büyük bir benzerlik taşıyan örneklerin bulunma ihtimali de yükselmiş olur. Bununla beraber Bosch Vilá'nın ileri sürdüğü teori, gelecekte ortaya çıkması muhtemel arkeolojik bulgu veya tarihî belgelerin neticesinde müspet bir gerçeklik kazanabilir.

\section{SONUÇ}

Bu çalışmada, mukarnas unsurunun tanımı ve onun isimlendirilmesine dair bazı görüşler ele alınmıştır. Buna göre kelimenin asıl olarak Arapça olduğu ve İslâm mimarisinin "islâmî" bir terimi olarak kullanılmaya başladığı tespit edilmiştir. Mukarnasın ilk defa ortaya çıkışı meselesine gelince konuya dair en önemli görüşleri inceledikten sonra bu unsurun İslâm dünyasının doğu kısmında zuhur edip bütün İslâm coğrafyasına yayılarak bir buçuk asırlık bir zaman dilimi içerisinde Mağrib mimarisinde merkezî bir yer edinmeye başlamış olduğu görülmüştür.

Mukarnasın menşeine dair çoğu anlaşmazlık ve tartışmaların şunlardan kaynaklandığına tanıklık edilmiştir:

Illk dönemden itibaren Mağrib mukarnası Maşrık bölgesindekinden farklı 


\section{$\operatorname{arts}=$}

olmuştur. Gerek yapı gerekse uygulama açısından bu farklılık gözlemlenmektedir. Osmanlı, Selçuklu ve Orta Asya mukarnasları gibi doğudaki örneklerden tamamen farklı tarzların ortaya çıkışının sebebi budur. Bu farklııılardan dolayı bazı araştırmacılar, mukarnasın İslâm coğrafyasında eşzamanlı olarak hem İran 'ın kuzey doğusunda hem de Afrika'nın kuzey ortasında iki bölgenin arasında temas noktası olmadan ortaya çıkmış olduğunu ileri sürmüşlerdir. Bazı araştırmacılar ise mukarnas diyebileceğimiz unsurun mahiyetini tahkik etmeden kubbe kasnaklarının köşelerindeki tromplar gibi mimarî unsurları mukarnas olarak kabuk etmişlerdir. Bununla beraber mevcut çoğu araştırmalar da ya yanlızca ayakta kalan mimarî eserlerden hareket edilerek ya da sadece tarihî incelemelere dayanarak yapılmıştır. Halbuki mukarnas unsurunun menşei gibi bir konunun, bu iki ciheti göz önünde bulunduran disiplinlerarası bir yaklaşımla incelenmesi gerektiği düşünülmektedir.

\section{KAYNAKÇA}

AFiFî, M. (2005). el-Kibâbü'l Eseriyye el-Bakiye bi Dilta Mısr fi'l-Asri'l İslâmî. Kahire: Mektebetü Zehrai'ş Şark.

ARSEVEN, C E. (1975). Sanat Ansiklopedisi. Ankara: Milli Eğitim Bakanlığı.

CRESWELL, K A C. (1974). The Muslim Architecture of Egypt. New York: Hacker Art Books.

ÇORUHLU, Y. (2000). "Isfahan Cuma Camii". DiA. C. XXII.

DE BEYLiÉ, G L. (1909). La Kalaa De Beni-Hammad: Une Capitale de Berbère de L'Afrique du Nord au XIe Siècle. Paris: Ernest Leroux.

EL-FÎRÛZÂBÂDÎ, M. (1998). el-Kamûsü'l-Muhît. Şam: Müessesetü'r-Risale.

EL-KÂŞÎ, G C. Miftâh-ül-Hesâb. Princeton University Arabic collection; cn. 9201656.03. Phase II.

EL-'UZRÎ, A. (1988). Nusûs 'ani'l Endelüs min Kitâb Tersi'ü'l Ehbâr ve Tenvî̀'ü'l Esâr ve'l Büstân fi Gara'ibi'l Büldân ve'l Mesâlik ilâ Cemi'i'l Memâlik. (Tah. A. elAhvânî). Madrid: İslâm Araştırmaları Enstitüsü yayınları.

ES-SÂGANÎ, R. (1979). et-Tekmile ve'z-zeylve's-sıle li-kitâbitaci'l-lugave'ssıhahi'l-Arabiyye. Kahire: Darü'l-Kütüp.

Ez-Zebîdî, M. (1978). Tâcu'l-'Arûs min Cevâhiri'l-Kâmûs. Küveyt: Daru'l-Hidaye. GRABAR, O. (1978). The Alhambra. Cambridge: MA Harvard University Press. GUALIS, G M B. (2000). "Couronnement des Rois d'Aragon". L'Art Mudejar: 
l'esthetique Islamique dans l'art chretien. Edisud.

IDRIS, H R. (1992). eddevletü's-Sanhaciyye Tarihu Ifrikiyye fi Ahdi Benî Zîrî Minel karn 10 ile'l karn 12. (Çev. H. es-Sahlî). Beyrut: Darü'I Garb el-islâmî.

isMAilL, O. (1993). Tarihü'l Imareti'l İslâmiyye ve'l Fünuni't Tatbîkiyye bi'l Magribi'l Aksâ. Rabat: el-Hilalü'l Arabiyye.

MALDONADO, B P. (2010). el-Imâretü'l-islâmiyye fi'l-Endelüs. (Çev. A. elMenufi). Kahire: el-Merkezü'l-Kavmi li't-Terceme.

MÜLÂYIM， S. (2006). "Mukarnas: İslâm mimarisinde uygulanan bir geçiş unsuru", DIA. C. XXXI.

RIZIK, A. (2000). Mu'cemu mustalahati'l-imare ve'l-fünuni'l-islâmiyye. Kahire: Mektebetu Medbuli.

SEYYID, E. (1995). "Fâtımîler". DiA. C. XII.

ŞAFIII, F. (1982). el-imaretü'l-Arabiyyetü'l-Islâmiyye. Riad: Câmiatü'l-Melik Suud. 